\title{
Norois
}

Environnement, aménagement, société

$237 \mid 2015$

Diversité des paysages fluviaux

\section{Corps et territoire. Arts et littérature à travers l'Europe et l'Amérique}

\section{Emmanuel Jaurand}

\section{(2) OpenEdition \\ 1 Journals}

Édition électronique

URL : https://journals.openedition.org/norois/5816

DOI : $10.4000 /$ norois.5816

ISBN : 978-2-7535-5086-5

ISSN : $1760-8546$

Éditeur

Presses universitaires de Rennes

Édition imprimée

Date de publication : 31 décembre 2015

Pagination : 117

ISBN : 978-2-7535-5084-1

ISSN : 0029-182X

\section{Référence électronique}

Emmanuel Jaurand, «Corps et territoire. Arts et littérature à travers l'Europe et l'Amérique », Norois [En ligne], 237 | 2015, mis en ligne le 31 décembre 2015, consulté le 28 janvier 2022. URL : http:// journals.openedition.org/norois/5816 ; DOI : https://doi.org/10.4000/norois.5816

\section{(c) Tous droits réservés}



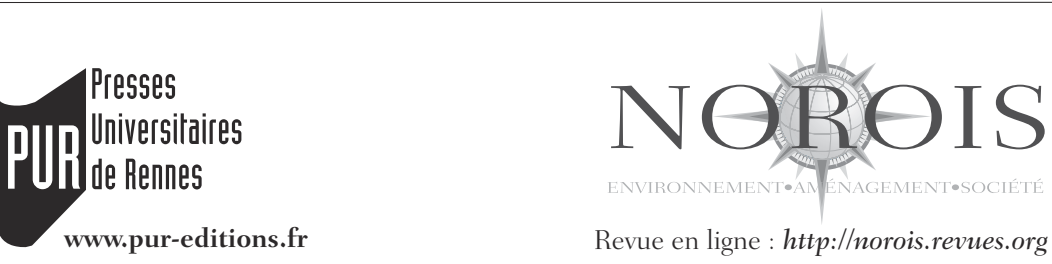

\section{COMPTES RENDUS BIBLIOGRAPHIQUES}

Eva Tilly, Arnaud Duprat (dir.), 2014. Corps et territoire. Arts et littérature à travers l'Europe et l'Amérique, Rennes, PUR, coll. «Des Sociétés », 298 p.

L'ouvrage Corps et territoire est issu de plusieurs journées d'études organisées par nos collègues de l'équipe GRADIVA-ERIMIT (Equipe de Recherches Interlangues : Mémoire, Identités, Territoires) de l'université Rennes 2 et ayant réuni des spécialistes de différentes langues et littératures. Lidée centrale de l'ouvrage est que les œuvres littéraires et artistiques, à travers les représentations du corps et de ses relations avec l'espace, nous transmettent des émotions (ressenties à travers nos corps) et permettent ainsi la projection des œuvres dans le monde. Alors que la géographie française s'intéresse aux spatialités du corps depuis les années 2000 , on voit ici que les relations entre les corps et les environnements dans lesquels ils circulent sont prises dans leur sens métaphorique. Il n'empêche que les exemples proposés dans l'ouvrage (le corps dans les westerns ou les films d'Almodovar notamment) montrent clairement le rôle du corps dans la construction identitaire de l'espace, même pris au dans sa dimension imaginaire. L'ouvrage, principalement centré sur des productions littéraires et filmiques de pays européens et des États-Unis, pourra donc intéresser au premier chef des spécialistes de géographie culturelle.

Emmanuel JAURAND Université d'Angers

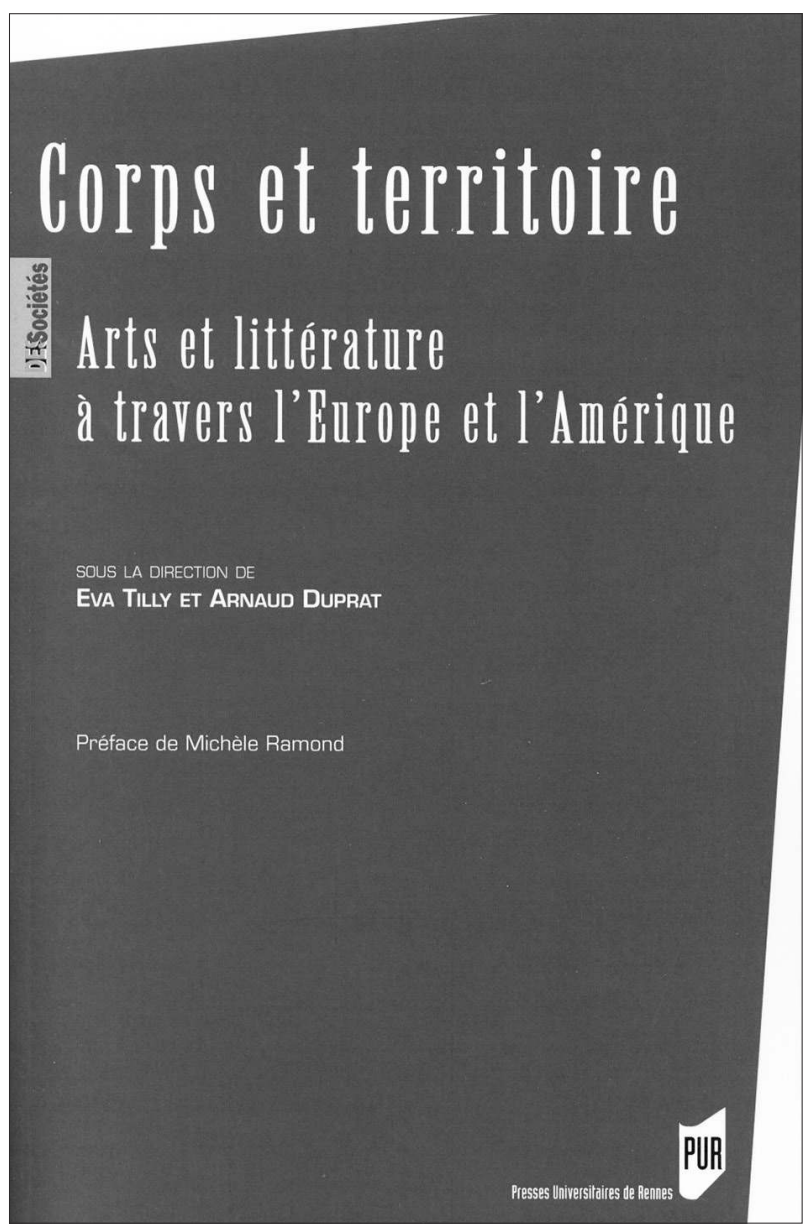

